\title{
Pericardiocentesis and systemic cytotoxic chemotherapy in the management of cardiac tamponade secondary to disseminated breast carcinoma
}

\author{
SUNDARESWARAN RAMAKRISHNAN, * ANDREW J MARSHALL, $†$ \\ JOHN G PICKARD, * CHRISTOPHER J TYRRELL * \\ From the Departments of ${ }^{\star}$ Radiotherapy and Oncology, and +Cardiology, Plymouth General Hospital, \\ Plymouth
}

SUMMARY Three patients with cardiac tamponade secondary to disseminated breast carcinomawere treated by pericardiocentesis followed by systemic cytotoxic chemotherapy. This approach controlled pericardial effusion in all the patients and extended their survival.

Neoplastic cardiac tamponade is one of the emergencies of clinical oncology. It is a potential life threatening complication of disseminated malignant disease and can cause sudden death. The outlook in general is appalling, and despite treatment many patients survive for only 4-5 months. ${ }^{1}$ The choice of appropriate therapy can be difficult and the optimal management remains controversial. Vigorous treatment is often not suitable for patients who are debilitated with advanced cancer and haemodynamically compromised. None the less, in tamponade secondary to metastatic breast cancer, a vigorous approach is indicated because breast carcinoma is a potentially controllable disease for which there is effective systemic treatment. We present three cases of proven malignant cardiac tamponade secondary to disseminated breast carcinoma that we treated by pericardiocentesis followed by systemic cytotoxic chemotherapy.

\section{Patients and methods}

From 1981 to 1985,722 new patients with breast carcinoma were seen at the Department of Radiotherapy and Oncology, Plymouth. In three $(0.4 \%)$ patients clinically significant malignant pericardial effusion developed with symptoms and signs of cardiac tamponade. All three patients had dissemin-

\footnotetext{
Requests for reprints to Dr S Ramakrishnan, Department of Radiotherapy and Oncology, Plymouth General Hospital, Freedom Fields, Plymouth, Devon PL4 7JJ.
}

Accepted for publication 16 May 1988 ated breast carcinoma when tamponade developed $\infty_{\infty}^{\infty}$ The diagnosis of cardiac tamponade was made on clinical examination, chest $x$ ray, and electro $\frac{\text { ? }}{3}$ cardiogram and was confirmed by echocardiography All the patients underwent percutaneous peri cardiocentesis for diagnostic and therapeutic pur poses. Afterwards they were given systemic cytotoxic chemotherapy as outpatients and their response was monitored by following their clinical condition, seria? chest $x$ rays, and echocardiograms. The treatmen was well tolerated with minimal side effects. In one of our patients early vinca neuropathy developed ando there was no cardiotoxicity with doxorubicin in the dosage used (total dose less than $550 \mathrm{mg} / \mathrm{m}^{2}$ ) Survival was calculated from the date of peri cardiocentesis to the date of death.

\section{Results}

The table shows the characteristics of our patients은. All our patients were post-menopausal, the average age when cardiac tamponade developed was 58.3 years. The mean interval between diagnosis of breas carcinoma and development of tamponade was $32 \cdot 7 \mathrm{w}$ months (range 0 to 70 months). None of our patients had previous cytotoxic chemotherapy and patients and 3 had previous endocrine treatment. All ouf patients had evidence of metastatic disease at sites other than the pericardium when the effusion presen $\frac{0}{0}$ ted. The pericardial aspirate (mean volume $716 \mathrm{~m}$ (range $150-1350 \mathrm{ml}$ )) in all the cases was an exudate containing adenocarcinoma cells. The mean surviva was 14.7 months (range 14 to 16 months). In all the 
Table 1 Patient characteristics

\begin{tabular}{|c|c|c|c|c|c|c|}
\hline $\begin{array}{l}\text { Patient } \\
\text { No }\end{array}$ & $\begin{array}{l}\text { Age at } \\
\text { diagnosis of } \\
\text { cardiac } \\
\text { tamponade } \\
\text { (yr) }\end{array}$ & $\begin{array}{l}\text { Interval between } \\
\text { diagnosis of } \\
\text { breast cancer } \\
\text { and development } \\
\text { of cardiac } \\
\text { tamponade (mnth) }\end{array}$ & $\begin{array}{l}\text { Previous } \\
\text { treatment }\end{array}$ & $\begin{array}{l}\text { Post-pericardiocentesis } \\
\text { systemic chemotherapy }\end{array}$ & $\begin{array}{l}\text { Survival } \\
\text { (mnth) }\end{array}$ & $\begin{array}{l}\text { Cause of } \\
\text { death }\end{array}$ \\
\hline 1 & 57 & 70 & $\begin{array}{l}\text { Surgery, palliative } \\
\text { radiotherapy, hormones }\end{array}$ & $\begin{array}{l}\text { Doxorubicin, vincristine, } \\
\text { and prednisolone }\end{array}$ & 14 & $\begin{array}{l}\text { Brain, lung, } \\
\text { and bone } \\
\text { metastase }\end{array}$ \\
\hline 2 & 69 & At presentation & Nil & $\begin{array}{l}\text { Doxorubicin, vincristine, } \\
\text { and prednisolone } \\
\text { ॠDoxorubicin, 5- } \\
\text { fluorouracil and } \\
\text { prednisolone }\end{array}$ & 14 & $\begin{array}{l}\text { Bone and } \\
\text { pleural } \\
\text { metastases }\end{array}$ \\
\hline 3 & 49 & 28 & $\begin{array}{l}\text { Surgery, loco-regional } \\
\text { radiotherapy, artificial } \\
\text { menopause, hormones }\end{array}$ & $\begin{array}{l}\text { Doxorubicin, vincristine, } \\
\text { and prednisolone } \\
\text { Mitomycin-C, 5- } \\
\text { fluorouracil, vindesine, } \\
\text { and prednisolone }\end{array}$ & 16 & $\begin{array}{l}\text { Lung, } \\
\text { pleural, } \\
\text { and intra- } \\
\text { abdominal } \\
\text { metastases }\end{array}$ \\
\hline
\end{tabular}

* Chemotherapy regime is altered because of progression of disease at sites other than the pericardium.

patients death was caused by progressive metastatic disease and the pericardial effusion did not recur.

\section{Discussion}

The accumulation of fluid in the pericardial space in patients with cancer is often not recognised until cardiac tamponade develops. The fluid usually reaccumulates rapidly after pericardiocentesis unless further definitive treatment is started. Such alternatives include the insertion of a pleuropericardial window, ${ }^{2}$ total or partial pericardiectomy, ${ }^{3}$ external radiotherapy, ${ }^{4}$ local instillation of a chemotherapeutic agent, ${ }^{5}$ local instillation of a sclerosing agent, ${ }^{6}$ and systemic chemotherapy. ${ }^{7}$ Press and Livingston ${ }^{*}$ in a recent review of documented reports of malignant pericardial effusion and tamponade noted that no definitive conclusion can be made about optimal management because there are no controlled trials and many series are small with heterogeneous distribution of tumour types, varying criteria for clinical response, and concurrent treatments.

Reynolds and Byrne advocate pericardiocentesis followed by systemic chemotherapy for malignant pericardial effusion in carcinoma of the breast. ${ }^{7}$ Local control of pericardial effusion was achieved and survival was extended but their survival data were incomplete. Bitran et al managed their patients with a pleuropericardial window and systemic chemotherapy. ${ }^{9}$ They achieved a median survival of 26 months (range 17-50 months). Direct comparisons are difficult but we do not believe that the establishment of a pleuropericardial window is necessary because none of our patients had evidence of recurrence of pericardial effusion at the time of death. Smith et al in a review of all reported cases of malignant pericardial effusions up to 1974 concluded that patients treated conservatively without surgical intervention had a longer symptom free interval than those given a pericardial window. ${ }^{10}$

Although the survival of patients with neoplastic cardiac tamponade is in general limited, ${ }^{1112}$ we believe that an active approach is warranted in those cases with tamponade secondary to breast carcinoma. Systemic cytotoxic chemotherapy after pericardiocentesis can achieve significant palliation in breast cancer, control pericardial effusion, prolong survival, with minimal toxicity, and give a good quality of life.

We thank Mrs Pauline Glover of the Radiotherapy Research Unit, for typing the paper. Mrs Glover is funded by the Cancer Research Campaign.

\section{References}

1 Ward C. Pericardial disease. Current Opinion in Cardiology 1986;1:422-8.

2 Hill GJ, Cohen BI. Pleural pericardial window for palliation of cardiac tamponade due to cancer. Cancer 1970;26:81-93.

3 Piehler JM, Pluth JR, Schaff HV, Danielson GK, Orszulak TA, Puga FJ. Surgical management of effusive pericardial disease: influence of extent of pericardial resection on clinical course. $J$ Thorac Cardiovasc Surg 1985;90:506-16.

4 Cham WC, Freiman AH, Carstens PHB, Chu FCH. Radiation therapy of cardiac and pericardial metastases. Radiology 1975;114:701-4.

5 Maher ER, Buchman R. Intrapericardial installation of bleomycin in malignant pericardial effusion. $\mathrm{Am}$ Heart J 1986;111:613-4.

6 Davis S, Sharma SM, Blumberg ED, Kim CS. Intrapericardial tetracycline for the management of cardiac tamponade secondary to malignant pericar- 
dial effusion. N Engl J Med 1978;299:1113-4.

7 Reynolds PM, Byrne MJ. The treatment of malignant pericardial effusion in carcinoma of the breast. Aust NZ J Med 1977;7:169-71.

8 Press OW, Livingston R. Management of malignant pericardial effusion and tamponade. JAMA 1987; 257:1088-92.

9 Bitran JD, Evans R, Brown C. The management of cardiac tamponade in patients with breast cancer. $J$
Surg Oncol 1984;27:42-4.

10 Smith FE, Lane M, Hudgin PT. Conservative man- $C$. agement of malignant pericardial effusion. Cancer $\overrightarrow{\vec{F}}$ 1974:33:47-57.

11 Haskell RJ, French WJ. Cardiac tamponade as the initial presentation in malignancy. Chest 1985;88:음 70-3.

12 Horgan JH. Cardiac tamponade. Br Med J 1987; 295:563-4. 